\title{
İrfan Tosuncuoğlu
}

Karabuk University, irfantosuncuoglu@karabuk.edu.tr, Karabuk-Turkey

http://dx.doi.org/10.12739/NWSA.2014.9.1.4C0176

\section{BAŞARILI BİR ÜNİVERSITE DİL PROGRAMINA DOĞRU}

\section{ÖzET}

Gelişen teknolojiyle hızlı bir şekilde küreselleşen dünyamızda çok çeşitli alanlarda kullanılan İngiliz dili, önemini gittikçe arttırmaktadır. Ülkeler arasındaki bilimsel, kültürel ve ekonomik ilişkilerin geliştirilmesinde dil bir köprü görevi görmekte ve bu ilişkilerin sürdürülmesinde önemli bir rol de üstlenmektedir. Bununla doğru orantılı olarak kariyer anlamında alanlarında yükselmek isteyen öğrenciler en az bir yabancı dil bilmek durumundadırlar. Ülkemizde de son yıllarda lisans programlarına dil hazırlık sınıfları konulmaya başlanmıştır. Bundaki amaç öğrencilerin bölümlerindeki lisans derslerinin en az 30'unu İngilizce olarak takip etmelerini sağlayacak İngilizce seviyelerine gelmelerini sağlamak ve onların gittikçe globalleşen dünyaya entegre olmaları ve birtakım kazanımlar elde etmeleridir. Çalışmamızda genel olarak yabancı dilin önemi belirtilmiş, Türkiye'de yabancı dil öğretiminin değerlendirilmesi yapılmış, bu alanda söz sahibi bilim insanlarının görüşlerine de yer verilmiştir. Dil hazırlık sınıflarındaki durum araştırılmış, öğrencilerin lisans programlarının talep ettiği dil seviyelerini yakalamaları için bir takım önerilerde bulunulmuştur.

Anahtar kelimeler: İngilizce Seviyesi, Metot, Hazırlık Programı, Edinim, İhtiyaç Analizi

\section{TOWARDS A SUCCESSFUL UNIVERSITY LANGUAGE PROGRAM}

\section{ABSTRACT}

Globalization is improving in the world as the result of technology, for that reason English language is becoming more and more important. It has a role of bridge in order to develop scientific, cultural, economical relations among the countries, and it has a position of continuing these relations. In direct proportion to that, the students who want to be at high positions in career should know at least one foreign language. It has been started to be put language preparatory classes in undergraduate programs, recently in our country. The aim of that, students should have knowledge of English in order to follow 30\% of the courses in their departments in English, and help them with integration to the global world and provide them with new gains. In our study the importance of foreign language was asserted, the general evaluation of teaching foreign language was done; the ideas of scholars were also given place. The general situation of language preparatory courses was evaluated, there were given several suggestions in order to catch the language levels demanded by the student's undergraduate programs.

Keywords: English Level, Method, Preparatory Program, Acquisition, Needs Analysis 


\section{GIRİŞ (INTRODUCTION) \\ 1.1. Yabancı Dil Bilmenin Gerekliliği \\ (Necessity of Knowing a Foreign Language)}

Günümüz bilgi ve iletişim teknolojilerinin hızlı gelişimleriyle küreselleşen dünyamızda, toplumların bilgi paylaşım süreçlerine işlevsellik kazandıran yabancı dil öğretimi, her geçen gün daha önemli hale gelmektedir. Bilginin doğru ve etkili olarak paylaşılması, ilgili yabancı dil veya yabancı dillerin etkili kullanımı ile doğrudan ilgilidir. Yabancı dilin etkili bir şekilde kullanımı için ilgili dile ait kuralları bilmek ve bu kuralları doğru olarak kullanmak gerekmektedir. En az bir yabancı dil bilmenin insanlara birçok avantaj getirdiği herkesçe de bilinmektedir. Insanlar dili kullanarak çok sayıda insanla iletişim kurup duygularını, düşüncelerini, ihtiyaçlarını veya sevgilerini çok rahat bir şekilde aktarabilirler. Peki, iletişim kurduğumuz insanların sayısını neden arttırmayalım? Ana dil kullanılarak kurulan iletişimin yabancı bir dilde kurulduğu düşünülürse, iletişime girilen insan sayısının da artacağını bilen birçok kişi, yabancl bir dili büyük bir hevesle öğrenmek, bunun bilincinde olan kuruluşlar da yabancı bir dili öğretmek amacındadır.

Insanoğlu yüzyıllar boyunca ihtiyaçlarını, korkularını, umutlarını, sevgilerini, acllarını birçok şekilde anlatmaya çalışmıştır: bazen birinin gösterdiği bir yakınlığa duygulanıp ă̆layarak, bazen de bir anlaşmadan sonra el sıkışarak... O ya da bu şekilde insanoğlu iletişimini sürdürmektedir. Dil, insan yaşamının merkezindedir (Cook, 1991:1). Cook'a göre dil; insanlara olan sevgimizi veya nefretimizi anlattığımız en önemli yollardan biridir, ideallerimize ulaşmak için ve meslek hayatımız için de önemlidir, aynı zamanda dil sanatsal açıdan doyum veya basit zevklerin kaynağıdır. Dili, hayatımızı planlamak ve geçmişi hatırlamak için kullanırız; dil yardımıyla fikirlerimizi ve deneyimlerimizi paylaşırız; aynı dili konuşan insanlara kendimizi tanıtırız.

Yabancl dil bilme gereksinimi milletler arasındaki ilişkilerin başlamasından bu yana devam edegelmektedir ve bu konu her geçen gün önemini artarak güncelliğini korumaktadır, (Yaşar, 1988:3). Dünya nüfusunun da yüzde altmışa yakın bir kısmının çok dilli olduğu belirtilmektedir ve çok dilliliğin elzem olduğu ve yabancı dil eğitiminin her zaman üzerinde durulan güncel bir konu olduğunu söyleyebiliriz (Meletli, 2007:7).

\subsection{Dünyadaki Yaygın Dillerin Güncel Kullanım Durumları (Current Usage of Widespread Languages in the World)}

Yakın geçmişe bir göz attığımızda yabancı diller arasında İngilizcenin diğer dillere göre giderek daha da yaygınlaştığını görmekteyiz. Özellikle İkinci Dünya Savaşı'nın sonundan itibaren, ABD'nin yeni bir sömürgeci güç olarak yükselişi ve hegemonyasıyla birlikte, Ingilizce uluslararası bir dil olarak Franslzcayı geride bırakmıs ve onun yerini almıştır. Ana dili İngilizce olanların sayısı 350- 400 milyon civarında tahmin edilip Mandarin Çince ve İspanyolcanın ardından üçüncü sırada yer alırken, İngilizceyi ikinci dil ya da yabancı dil olarak konuşanları da eklersek, İngilizce 1,8 milyar kişiyle bir numara olmaktadır. İspanyolca, İspanya ve Amerika'daki eski kolonileriyle sınırlıyken Mandarin Çince, Çin'de yoğunlaşmıştır. Öte yandan İngilizce Kuzey Amerika, Avrupa ve Avustralya kıtalarında ana dil olarak; Güney Asya, Doğu Asya, Avrupa, Afrika ve yerküreye saçılmış çok sayıda adada ikinci dil olarak konuşulmaktadır. Günümüzde, yabancı dil olarak dünyada en çok kullanllan dil İngilizcedir.

Avrupa'daki okullarda öğretilen yabancl dillerin istatistiksel oranına ilişkin rakamsal veriler incelendiğinde, İngilizcenin 
\%60, Fransızcanın \%30, Almancanın \%5, İspanyolcanın \%4 ve diğer dillerin o1 oranında öğretildiği anlaşılmaktadır (TBC: TFOE,2000:45). Verilerde de görüldüğü gibi, İngiliz dili öğretimi, diğer dillere göre oldukça etkin bir konumdadır.

Aynı rapora göre her bir dilde yayınlanan yılıık kitap sayısı rakam oranları ise: İngilizce 28, Çince ⒔3, Almanca ⒒8, Fransızca ㄱ.7, İspanyolca \%6.7, Japonca \%5.1, Rusça \%4.7, Portekizce \%4.5, Korece \%4.4, İtalyanca \%4, Hollandaca \%2.4, İsveççe \%1.6 ve diğer ⒌8 olarak ifade edilmektedir (TBC: TFOE, 2000:9). Verilerin incelenmesi sonucunda da görüldüğü üzere İngiliz dilinde yayınlanan kitapların sayısının dünyada yayınlanan kitapların dörtte birinden fazla (\%28) olduğu açıkça görülmektedir.

\subsection{Yabancı Dil Öğretimi Hakkında (About Foreign Language Teaching)}

Bütünleşen ve değişen dünyada İngilizce öğrenimine ve öğretimine verilmesi gereken önem birçoğumuz tarafından tartışılmaz bir gerçek olarak kabul edilmiştir. Yabancı bir dili öğrenmek, bu yeti sayesinde birçok bilgiyi çok daha kısa zamanda ve ucuza edinmek iyi bir düşüncedir; ama burada karşımıza çıkan sorun, yabancı dili "kime", "nasıl" öğretmek; bir başka deyişle, bilgiye ihtiyacı olacak insanların seçilmesi ve bu insanların eğitim öncesi ve eğitim aşamasında dikkate alınması gerekenlerin çok iyi belirlenmesi gerektiğinin eğitimciler tarafından çok iyi kavranması gerekliliğidir. Binbaşıoğlu (1975:14-15), başarıya giden yolu şu üç maddeyle açıklamıştır:

- Bireye, kendini "sürekli olarak geliştirme" gücünü kazandırmak.

- Bireyin, yetenekleri ile başarısı arasındaki ilişkiyi görmesini sağlamak.

- Bireyin, kendini gerektiği gibi tanıması ve girebileceği okul ya da mesleği, ilgi ve yeteneklerine göre seçmesini sağlamak.

Kocaman (1983:10) ise, yabancı dil öğretimini bir muasır medeniyete katılma çabası olarak görmekte ve şunları yazmaktadır: "Evrendeki ilgiye koşul olarak yurdumuzda da, özellikle Cumhuriyet döneminde, bu yolda yoğun çabalara tanık olmaktayız. Ancak bu konuda yeterli sonucun alınabildiğini söylemekten uzağız. Bunun nedenlerinden birisi, henüz kendi koşullarımıza uygun bir ders izlencesi, ders yöntem ve gereçleri geliştirememiş olmamızdır. Bunun yanında, yabancı dil öğretiminde çağdaş kavramları özümsemiş öğretici yetiştirme konusundaki eksikliğimiz de küçümsenmemelidir."

Diğer taraftan, dil öğretiminde kullanılan araç-gereçlerin öğrenci tarafından ilgi görmesi de önemli bir konudur. Öğrencinin ilgisini çekebilecek nitelikte ve içerikte hazırlanan materyaller öğrenciyi derse daha fazla bağlayacağından, istenilen amaçlara ulaşılmasında kolaylık sağlayacaktır. Bunu să̆larken de öğrencilerin ilgi ve ihtiyaçlarının iyi belirlenmesi gerekmektedir. "Olması gereken de müzakere yoluyla öğrencilerin de bu sisteme dâhil edilmesiyle amaca daha kolay ulaşılmasıdır." (Nunan 1993:62).

Bir üniversite, kendi toplumuna olduğu kadar uluslararası topluma ve insanlığa hizmet etmek için gençleri eğitir, yetiştirir ve farklı alanlarda araştırmaları destekler. Kendi toplumu için sağlık, teknoloji ve iş alanlarında çalışmalar yapar. Bir üniversite içinde bulunduğu, onu destekleyen toplumun ihtiyaç ve taleplerine cevap vermeli, ihtiyaçlarına karşılık gelmelidir. Nasıl ki iş alanında belirli bir ürün veya hizmete dair potansiyel pazarı belirlemek için pazar araştırması yapılmalı, aynı şekilde bu ihtiyaçları karşılamak için bir program tasarlanmadan önce de bilimsel bir ihtiyaç analizi 
yapılmalıdır. Yabancı dil için ihtiyaçlar tek tipte veya yapıda değildir. Bunlar çok çeşitlidirler ve değişik cevaplar gerektirirler.

Yoksul bir ülkede bir üniversitenin öğrencilerine ücretsiz ayakkabı vermeye karar verdiğini ve bundan sonrada öğrencilerin derslere bu ayakkabılarla gelmelerini şart koştuğunu farz edelim. Yönetim, muhtemelen ilk önce Matematik Bölümü'nden bir istatistikçiye danışır ve mevcut öğrencilerle yapılan bir araştırma neticesinde ortalama ayakkabı numarasının erkeklerde 42, kızlarda da 38 olduğuna karar verilir. Bu amaç için, kurup destekledikleri bir bağış fonundan gelen parayla, ayakkabı siparişi verirler. Binlerce ayakkabı yaptırıp eylülde eğitim ve öğretim yılı başladığında dağıtmaya başlarlar. Tabii ki, güvenlik görevlileri ayakkabısız gelen öğrencileri geri çevirdiklerinden, dönem başlangıcında tahminimizce öğrencilerin sadece \%50'si kabul edilebilir. Ayakkabılar öğrencilerin yarısına uymayabilir. Öğrenciler, ayakkabıları çok küçük veya çok büyük ayaklarına uydurmaya zorlarlarken, öğrencilerin \%40'nın ayaklarında ağrı ve acı oluşabilir ve ayakları su toplayabilir. Birkaç hafta sonra, hepsi aynı şekilde, giymeye dayanamadıklarından, öğrencilerin yalnızca ol'i derslere gelebilir. Bu durum, son zamanlarda pek çok üniversitenin, yoğun bir İngilizce hazırlık sınıfı açmalarına benzemektedir. Bildiğimiz gibi öğrenciler hangi bölümde olursa olsunlar, muafiyet sınavı sonuçlarına göre Hazırlık sınıflarında gereksinim duyup duymayacakları belirlenmektedir.

Bununla beraber, bizce yabancı dil eğitimi ve matematik eğitimi arasında paralellikler çizilebilir. Her ikisi de fikirlerin, kavramların, çerçevelerin, görüntülerin ve sistemlerin ifadesi, formülasyonu, oluşumu, gelişimi ve sadeleştirilmesi için gerekli araç ve yetilerden oluşmaktadır. Farklı uzmanlıklarla da olsa sadece tek bir matematik dili varken, konuşulan dillerin sayısı yaklaşık 7,000 civarındadır. Tahminen sadece birkaç yüz kadarı yazılı iletişimde kullanılmaktadır. Uluslararası dillerin sayısı daha da sınırlıdır. Almanca ve Latince şöyle dursun, yukarıda sayısal verilerde görüldüğü üzere İngilizce, Fransızca, İspanyolca, Rusça, Çince vb. uluslararası yayınlarda halen önemlidir.

\section{2. ÇALIŞMANIN ÖNEMI (RESEARCH SIGNIFICANCE)}

Bu çalışmada "Başarılı Bir Üniversite Dil Programına Doğru" başlığı altında yabancı dilin önemi belirtilmiş, Türkiye'de yabancı dil öğretiminin değerlendirilmesi yapılmış, bu alanda söz sahibi bilim insanlarının görüşlerine de yer verilmiştir.

Dil hazırlık sınıflarındaki durum araştırılmış, öğrencilerin lisans programlarının talep ettiği dil seviyelerini yakalamaları için bir takım önerilerde bulunulmuştur.

Çalışma bu konuda yapılacak benzer çalışmalara ışık tutma ve yol göstermesi bakımından önem arz etmektedir.

\section{PROBLEM (PROBLEM)}

\subsection{Türkiye'de Dil Eğitimi (Language Education in Turkey)}

Türkiye'de İngilizce, 1960'larda pek çok ortaokul ve lisede, az sayıda üniversitenin hazırlık programlarında okutulmaktaydı, bunların en çok bilineni Orta Doğu Teknik Üniversitesi'nin bir yıllık hazırlık programıdır. Ana dili İngilizce olan öğretim elemanları da buralarda görev yapmaktaydılar. Bugün çok daha fazla sayıda üniversite ve yüksekokullar, bütün bölümlerdeki olmasa da en azından bazı bölümlerdeki öğrencileri için müfredatlarına hazırlık sınıfı programlarını eklemişlerdir.

Türkiye'deki Dil öğretimi ile ilgili olarak Cumhurbaşkanı Abdullah Gül, Yükseköğretim Kurulunda yaptığı konuşmada, Türkiye'de yabancl dil bilgisi durumundan memnuniyetsizliğini de dile 
getirmiştir: "Yabancı dil eğitimi konusunda bizden daha başarısız bir ülke bilmiyorum. Bunu açıkça söylüyorum. Bunu ilköğretim ve üniversite eğitimi için de söylüyorum. Nitelikli addettiğimiz öğrencilerin yurt dışına gittiklerinde nasıl utandığını hepimiz biliyoruz. Uluslararası ortamda en büyük dezavantajımız gençlerin ikinci bir dil bilmemesidir. İkinci bir dil bilenler çok az sayıdadır. Bu şekilde devam etmek mümkün müdür?" demiştir.1

Bununla beraber Türkiye'den daha başarısız ülkeler de vardır. Örneğin Malezya'da problem daha büyük ve çelişkilidir. Malezya Eğitim Bakanı Yardımcısı Tan Sri Muhyiddin Yasin, yakın zamanda, "Beş yılı ortaokulda olmak üzere, 13 yılı kapsayan bir ulusal eğitim sistemi, öğrencilerimize iyi bir İngilizce kavrayışını nasıl halen daha kazandıramamaktadır? Ben şahsen bu soruyu cevaplayamıyorum." Bir gözden geçirme, güçsüzlüğün İngilizce öğretmeni azlığından mı, materyal ve ekipman yetersizliğinden mi, yoksa başka sebeplerden mi olduğunu belirleyebilir." demiştir. Ingiliz diline hâkimiyetin önemli olduğunu, çünkü uluslararası iletişimde ve ekonomide asıl dil olduğunu da ifade etmiştir. ${ }^{2}$

Buna paralel olarak Can (2005:10), Türkiye'de ilköğretim, ortaöğretim ve bazı yükseköğretim programlarında yabancı dil olarak çoğunlukla İngilizce öğretilmekte olduğunu ve Türkiye'de söz konusu kademelerin programlarında İngilizcenin önem verilen bir ders olarak yer almasına rağmen, bu derslerle Ingilizce öğretiminin formal eğitim süreci içinde, çözümlenemeyen bir sorun olarak varlığını koruduğunu vurgulamaktadır.

Demirel de (2004:11), yükseköğretim kurumlarında gerçekleştirilen yabancı dil öğretimine ilişkin görüşlerini: "Yükseköğretim kurumlarında yabancl dil öğretimi ise bu kurumların özelliğine ve yabancı dil öğretimi konusunda benimsedikleri siyasaya bağlı olarak yürütülmektedir." şeklinde belirtmektedir. Aynı şekilde Sert (2008), Türkiye'de yıllar boyunca eğitim programlarında etkin bir şekilde yer almasına karşın yabancı dil dersleri, öğrencilerin yabancı dili etkili kullanabilme konusundaki yetileri istenilen seviyede olmadığının altını çizmekte ve Little da (1995), bu durumun öğrencilerin, dili öğrenme ve iletişim bilincini önemli ölçüde geliştirmemelerinden kaynaklandığını ifade etmektedir

\subsection{Dil Hazırlık Eğitimi}

\section{(Language Preparatory Education)}

Halen Türkiye'de, YÖK (Yüksek Öğretim Kurulu) yönergelerine göre öğrenciler, üniversite ve yüksekokullara doğrudan kabul edilmekte; ancak öğrencilerinin derslerin en az \%30'unu ve \%100'ünü İngilizce takip etmelerini zorunlu kllan birimlerde, öğrenciler İngilizcenin eğitim ve değerlendirme dili olduğu dersleri alabilsinler diye, yoğun İngilizce eğitimi için bir yıl hazırlık programı okumak zorundadırlar. Sınavları ve tatilleri çıkardıktan sonra bu, haftada yirmi dört veya yirmi sekiz saatten, yaklaşık otuz hafta ya da 720 ila 840 saatlik, bir akademik yıldan oluşan iki dönemlik yoğun bir eğitimdir.

İngilizce hazırlık programlarına dahil olan bizler, öğrencilerin altı veya daha fazla yıl süren ilk ve orta öğretimde gördükleri İngilizcelerini arzu edilen düzeyde geliştiremezken, onları üniversite seviyesinde derslerin en az o30'unu İngilizce takip edebilmeleri için, yaklaşık 9 ay sürecek olan hazırlık programlarına dahil etmekteyiz. Böyle bir hazırlık programında bize göre aşă̆ıdaki olumsuz durumlar bulunmaktadır:

\footnotetext{
(Yükseköğretim Kurulu)
}

2 (Bernama, 2011) 
- Tüm öğrencilerin, hazırlık programı olan üniversitelerdeki programlar için iki dönemlik yoğun İngilizceye ihtiyaç duydukları varsayılmaktadır. Muafiyet sınavları kurumsallaşırken düşük seviyedeki öğrenci ve gruplar için yardımcı(ek) dersler ya da destek düşünülmemektedir.

- Kabul edilen öğrencilerin hepsinin aynı yeterlik seviyesine ve aynı ara seviyeye yerleştirilmektedir. Bu öğrencilerin çoğu, başarılarının imkânsız olduğuna inandıkları bir programla karşılaştıklarında hevesleri kırılmaktadır.

- Tüm öğrencilerin önceden belirlenmiş bir seviyede akademik amaçlar için İngilizce'ye ihtiyaç duydukları varsayılmaktadır. ESP (English for Spesific Purpose/Belirli Amaçlar için İngilizce)'de, eğer bir öğrenci, herhangi bir üniversitede, bir birime kabul edilirse, kabul eden bölüm ve eğitim vermekten sorumlu dil birimi, öğrencinin ilerideki yıllarda mesleğiyle ilgili devam edeceği programa göre hedef, materyal araç ve gereçleri belirlememektedir. Eğitim dili İngilizce olmayan bölümlerde okuyacak olan öğrencilerin, iki dönemde yaklaşık otuz hafta boyunca haftada yirmi dört ile yirmi sekiz saat içinde, programdan yeterli edinimi sağlamak için programda başarılı olmaları gerekmemektedir. Yani hazırlık eğitiminde başarısız olsalar bile, devamsızlıktan kalmadıkları takdirde bir üst sınıfa geçebilmektedirler. Eğer öğrenciler devamsızlıktan kalmadılarsa, bazı bölümlerde dersler İngilizce olarak anlatılmadığı için öğrenciler hazırlık sınıfını geçemeseler bile lisans programlarına devam edebilmektedirler.

- Bazı bölümlerdeki öğrenciler hazırlık programı görüp görmemelerinin, ana programları (lisans), gelecekteki işverenleri ya da toplumları için önemli olmadığını düşünmekte ve hazırlık sınıfının kendilerine 1 yıl zaman kaybı ve ek maliyet getirdiğini düşünmektedirler. Buna ek olarak öğrencilerin, büyük çoğunluğunun değilse bile önemli bir kısmının hazırlık programlarını ciddiye almadıklarını gösteren davranışlarını da zaman zaman gözlemledik. Çoğu aile bütçelerinin elverdiği ölçüde derslere gelmeyip dışarıda zaman geçirmekte veya bazen bilinçli bir şekilde derse geç gelmekte, verilen ödevleri yapmamakta ve dersleri umursamamaktadır.

\section{4. ÇÖZÜME DOĞRU (TOWARDS THE SOLUTION)}

Çoğu hazırlık birimlerinde durum böyle olsa da, bu çözümlenemeyecek bir sorun değildir. Bu ve benzeri problemler ve aksaklıklar bizce devam etmemelidir. Aslında bu sorunların çoğu diğer dil hazırlık programlarında ders veren öğretim elamanları tarafından da karşılaşılan meselelerdir. Bu ülkemiz üniversitelerinde karşılaşılan meseleler, dünyanın birçok başka yerindeki yükseköğretim kurumlarında da karşılaşılmaktadır. Hazırlık sınıflarına olan ilgiyi aşağıdaki şekilde özetleyebiliriz:

- Genellikle, toplumumuzun pek çok kademe ve kesimi, bir kişinin ana dilinden başka, birden fazla dil bilmesinin değerini takdir etmektedir. Bu durum da öğrenci ve diğer kişileri cezp etmektedir.

- Hükümet ve toplumumuz, bina ve derslik, eğitim kadrosu, materyal ve malzeme ihtiyacı için hatırı sayılır kaynak ayırmaya hazırdır. Örneğin 2007 yılında kurulan Karabük Üniversitesi ve üniversitedeki tesis ve binalar ve dil laboratuvarı, devletin desteğinin yanı sıra Karabük'ün iş adamları ve kurumları 
tarafından, Üniversitenin kurulduğu günden itibaren finanse edilmektedir.

- Bazı üniversite ve yüksekokullarda hazırlık programları olan bölümlerin sayısı artış göstermektedir. Örneğin 2012-2013 akademik yılında Karabük Üniversitesi'nde açılan yeni bölümlerin hepsine 20.06.2012 tarihli senato kararıyla hazırlık programları konmuştur.

- Üniversite yönetimleri, artan öğrenci sayısına bağlı olarak, Dil alanında öğretim elemanı sayısını, verdiği akademik kadro alım ilanlarıyla arttırmaktadır. Günümüzde en fazla öğretim elemanı istihdamı İngilizce alanında olmaktadır.

\section{TARTIŞMA VE BULGULAR (DISCUSSION AND FINDINGS)}

Bir yabancı dil hazırlık programı kurup devam ettirmek ve onu üniversitenin eğitim faaliyetlerinin işine yarar, saygın, değerli ve hayati bir parçasına dönüştürmek için aşağıdaki hususlar gereklidir;

\subsection{Ihtiyaç Analizi (Needs Analysis)}

Bir yabancı dil olarak İngilizceye olan ihtiyaç, yabancı diller yüksekokulları tarafından bir yıllık İngilizce hazırlığı zorunlu kılan fakülte ve bölümlerle görüşülerek bilinçli ve açık bir şekilde tanımlanmalıdır. Programların yoğunluğu ve süresi belirlenen ihtiyaçların karşılanmasıyla doğru orantılıdır.

Bir ihtiyaç analizi kesinlikle, farklı fakülte ve okulların farklı ihtiyaçları olduğunu ortaya koymaktadır. Bu, üniversitelerin tek bir hazırlık ders programını bırakıp birtakım kurlardan oluşan ders programlarına geçmeleri anlamına gelecektir. Bu, her bir ayrı program için ayrı ayrı tasarlanıp yazılmış eğitim materyali anlamına da gelmektedir.

\subsection{Kur Sistemli/Çok Seviyeli Dil Eğitimi Programları (Course of Studies-System/Multi-Level Language Teaching Programs)}

Kabul edilen öğrenciler için, akademik öğretim yılı başlamadan önce seviye tespit ve yerleştirme testleri uygulanmalı; sonuçlar, öğrencileri başarılı olabilecekleri ve sıkılmayacakları seviyelere yerleştirilmek için kullanılmalıdır. Nasıl ki herhangi bir okuldaki bütün öğrencilere sadece tek bir numara ayakkabı verilemezse, öğrenciler en baştan düşük başarı şansları olduğunu fark eder ya da bundan kaygı duyarlarsa motivasyonları kırılabilir. Öğrenciler yerleştirildikleri seviyede başarılı olup olamayacaklarını kısa zamanda fark ederler ve daha önce de bahsedildiği üzere, eğer öğrenciler başaramayacaklarını fark eder ya da buna inanırlarsa büyük bir şevkleri azalabilir ya da hayal kırıklıklarına uğrayabilirler. Bu tip öğrenciler sadece öğrenmemekle ya da öğrenmek istememekle kalmazlar, sınıfta da iltihaplı bir yara haline gelip çeşitli disiplin sorunları da ortaya çıkarabilirler.

Her bir öğrenci zorlanmayacağı bir seviyeye de yerleştirilmemelidir. Belli bir zorluk derecesi olmaksızın, öğrenciler zorlanmazlar, sıkılırlar ve öğrenmezler. Sıkılmak da istek ve şevk kırıcı bir durumdur. Dolayısıyla öğrenciler sorunlarla baş etmeye zorlanacakları ve onları teşvik edecek seviyelere yerleştirilmelidir. Bununla beraber, üniversitede belirli zamanlarda yapllan İngilizce muafiyet sınavları için yapılan duyurulardan her öğrencinin haberdar olması gerekir. Eğer İngilizcede belirli bir düzeydeki öğrenci seviye tespit sınavına girmediği takdirde seviyesi belirlenememekte ve başlangıç guruplarına dahil edilmektedir. Öğrencilerin, kendilerinden daha düşük bir seviyede olduğu bir sınıfta bulunmaları, onlar için 
zaman kaybıdır, bu durum diğer öğrencilerin cesaretini kırabilir ve motivasyonlarını azaltabilir.

Yukarıda da değinildiği üzere, kaliteli bir program için akademik birimlerin ve öğrencilerin ihtiyaçlarını karşılayan çokkulvarlı, çok-seviyeli bir program esastır. Çok-seviyeli bir program, altı seviyeye kadar eğitim malzemesi gerektirmektedir: başlangıç, temel, ortanın altı, orta, ortanın üstü, ileri. Daha önceki eğitim ve öğretim hayatı deneyimlerimize göre, doğal olarak az sayıda öğrenci muafiyet sınavını geçmektedir, biraz fazlası yüksek seviyelere ve çoğunluğu aşağı seviyelere yerleştirilmektedir.

\subsection{Bütünlük (Unity)}

Bir İngilizce hazırlık dil programının bütünlüğü, üniversitesinin saygınlık ve itibarının temelidir. EFL hazırlık programının bütünlüğü aynı zamanda her fakülte ya da akademik birimin sağlamayı umduğu kalitenin temellerinden biridir. Üstün başarının kazanılması yüksek bütünlüklü bir program olmaksızın imkânsızdır. Adil olmayan bir dil öğretim programının temelini oluşturan ders ve program düzeni, tıpkı gerekli oranda çimentonun kum ve çakılla karıştırılmaması ya da gerekli miktarda inşaat demiri kullanılmamasının ilk depremle ya da normal kullanım sonucu bile binanın çökmesine yol açacağı gibi, başarısızlığa neden olur. Adil olmama iki unsurdan kaynaklanır: sınama ve not verme. Daha iyi notlar alabilmek için testler ve sınavlar gerekli başarı düzeyinin altındaki seviyelerde hazırlanabilir ya da çan eğrisi veya genel not eklemeyle notlar iyileştirilebilir.

Çok sayıda öğrenciyi geçirme ve notlarını şişirme baskısı değişik yönlerden gelebilir. Toplumumuzda bazı kurum veya kimseler, ya kendi tanıdıklarının ya da tanıdıklarının yanı sıra, ihtiyacı olan tüm öğrencilerin notlarını, kimseye iltimas geçmeden, iyi niyet olarak yükseltilmesini isteyebilir. Liyakatli ve başarı vaat eden aday öğrencilerin hakkaniyetli bir şekilde değerlendirilmesine dayanan bir akademik birime önem verilmeyebilir. Bir hastane, hazırlık sınıfını tekrar tekrar geçmek için yardım almış olan, appendix ile annex arasındaki ya da mikro ve makro infüzyon arasındaki farkı bilmeyen bir yeni mezunu istemez. Ne de bir hasta veya yakınları anterior(ön), ve posterior (arka), arasındaki farkı bilmediği için kanserli beynin sağlıklı kısımlarını kesip alan bir doktor ister.

\subsection{Yetkin ve Nitelikli Yüksekokul (Competent and Qualified School of Higher Education)}

Yeterli sayıda, nitelikli akademik ve idari personel başarılı bir program için çok önemlidir. Her öğrenci, bir eğitmenin sağlayabileceği ölçüde, kişisel ilgi ve geri beslemeye gereksinim duyar. Sınıfta ev ödevlerinin ve diğer ödevlerin düzeltilmesinin yanı sıra, katılım ve geri bildirim de öğrenci motivasyonunun beslenmesi ve doğru öğrenme için önemlidir. Bir eğitim ve öğretim kurumunda kaliteli öğretim elemanı ve ilgili alan kökenli tecrübeli yöneticilerin bulunması elzemdir. Bölüm, fakülte ve yüksekokullarda dâhili ve harici evrak işlerini yürütmek için üniversite personel daire başkanlığı tarafından iki dilli ofis personeli sağlanmalı, dil programlarının denetimi ise üniversitenin kendisi tarafından yapılmalıdır. Yükseköğretim eğitim kalitesinin arttırılabilmesi için, eğitim araç gereç ve malzemelerinin geliştirilmesi ve değerlendirilmesi için komisyon ve birimlerin kurulması son derece önemlidir, örneğin materyal geliştirme ofisi gibi. Son olarak üniversitelerimizde verilen ücretler eğitimli ve deneyimli, ana dili İngilizce olan öğretim elemanlarını uzun süreliğine tutmaya yetmese de, ilk aşamada 
kazanılacak olan tecrübenin çekiciliği birçoğunu birkaç yıllığına tutmaya yetmelidir.

\subsection{Uygun Eğitim Materyalleri (Suitable Education Materials)}

Ingilizce öğretim materyal ve malzemeleri için devasa bir pazar vardır ve dünya çapında giderek büyümektedir. Kaliteli bir İngilizce öğretimi için akademik birimlerin ve öğrencilerin ihtiyaçlarını karşılayan çok-kurlu, çok-seviyeli bir program esastır. Çok-seviyeli bir program altı seviyeye kadar eğitim malzemesi gerektirmektedir: Başlangıç, temel, ortanın altı, orta, ortanın üstü, ileri. En az iki ESP(English for Spesific Purposes-Özel amaçlar için Ingilizce) kuru olan çok-kurlu bir program, her bir farklı kur için uygun eğitim materyal ve malzemesi gerekir. Pazarda pek çok uzmanlık için ESP materyal ve malzemesi vardır. Bununla beraber bazı materyallerin kurum içinde, örneğin ders yükü az olan fakülte öğretim elemanlarından oluşan bir materyal geliştirme ofisi tarafından, geliştirilmesi gerekebilir. Altı seviyelik, her bir kur için materyal hazırlamak bir dönemden, hatta bazı düzeltmelerle beraber, bir yıldan fazla zaman alabilir. Gerekli ve arzu edilen malzemeyi yazmak, düzenlemek ve revizyonunu yapmak birkaç yıl dahi sürebilir. Gerekli olan zaman, bu işe ayrılan personel sayısına, kaynağına, ihtiyaç ve hedeflerin değişip değişmemesine bağlıdır. Bununla beraber, bir geçiş süreci için daha önce yayınlanmış malzemeler destek ve yardımcı materyaller olarak kullanılabilir.

\section{SONUÇ VE ÖNERILER (CONCLUSION AND SUGGESTIONS)}

Başarılı bir üniversite dil hazırlık programı kurmak için, motivasyon ve bütünlük temel alınmalıdır, bu iki öğe programın gelişiminde önemli bir rol oynamalıdır. Mevcut durumda çoğu yoğun İngilizce hazırlık sınıfı programı, tek beden hepsine uyar mantığıyla, tek bir ara seviyede İngilizceden ibarettir. Yabancı dil ihtiyaçları çok çeşitlidir ve değişik amaçlar içindir. Üniversite programları onlari ikame ve finanse eden okulların, cemiyetin ve toplumun ihtiyaçlarına cevap verecek nitelikte olmalıdır. Türkiye'nin İngilizceye bir uluslararası iletişim ve eğitim, bilim, teknoloji, tıp, ticaret ve finansın tüm alanlarında araştırma ve yayınlama aracı olarak ihtiyacı vardır. Bugün çok daha fazla sayıda üniversite bütün bölümlerde öğrenim gören öğrencilerine olmasa bile en azından bazı bölümlerdeki öğrencileri için hazırlık sınıfı programları koymuşlardır.

Bununla beraber motivasyonun bir parçası olarak bilgi ve yeti arzusuna ek olarak, bütünlükle sağlanabilen gayret ve sıkı bir çalışma da şarttır. Dokuz aylık bir İnilizce hazırlık sınıfı programında hedef, ilk ve orta öğretimleri süresince altı veya daha fazla yıl süren dil çalışmaları neticesinde çok daha mütevazı hedefleri gerçekleştiremezlerken, öğrencilerin üniversite seviyesinde derslerin en az $\%$ 30'unu İngilizcede takip edebilmelerini sağlayacak dil yetilerini kazandırmaktır. Mevcut Ingilizce hazırlık programını oluşturulurken yapılan bazı ileriye dönük varsayımlar incelenip analiz edilmelidir. Mevcut programlardaki pek çok güçlü taraf, mükemmelliğin temeli olarak inşa edilebilir ve kullanllabilir. Bir yabancı dil hazırlık programı kurup devam ettirmek ve onu üniversitenin eğitim faaliyetlerinin işine yarar, saygın, değerli ve hayati bir parçasına dönüştürmek için şu motivasyon dayanakları elzemdir: Bir ihtiyaç analizi, çok-seviyeli ve çok-kurlu dil eğitimi veren programlar, uygun eğitim materyalleri ve yetkin bir yüksekokul. Öğrencileri sınamada, değerlendirmede ve yükseltmede bütünlük de çok önemlidir. Bilinçli ve ölçülü, dikkatlice planlanan ve yönetilen, iyi bir kadroya sahip, bir 
mekânda kurulan ve yeterli düzeyde finanse edilen programlar başarının temelini oluşturmaktadır.

\section{KAYNAKLAR (REFERENCES)}

- Can, A., (2005). Ingilizce öğretmeni yetiştirme programının kazandırdığı konu alanı öğretmen yeterliklerinin standartlara göre değerlendirilmesi. Doktora Tezi [YÖK Tez No:205177]. Ankara Üniversitesi Eğitim Bilimleri Enstitüsü, Ankara.

- Bernama. (2011, August 6). Muhyiddin: Review Teaching Of English In Schools. Retrieved August 12, 2011, from bernama.com: http: / / strongmail.multiview. com/track?type=click\&mailingid=20157 52 \&messageid=2015752\&databaseid=Mailing. DS15752.2015752.1043\&ser ial=1245140271\&emailid=wspeachy@yahoo. com\&userid=9053961\&extra=\& \&\&2070\&\&\&http: / / multibriefs. com/ViewLink.php?i=4e41774216247

- Binbaşıoğlu, C., (1975). Rehberlik, Ankara: Yargıcıoğlu Matbaası.

- Cook, V., (1991). Second Language Learning and Language Teaching. New York: Routledge, Chapman and Hall, Inc.

- Demircan, Ö., (1997). Yabancı Dil Eğitimi mi Yabancı Dille Eğitim mi? Gösteri Dergisi.

- Demirel, Ö., (2004). Yabancı dil öğretimi: Dil pasaportu, dil biyografisi, dil dosyası (2. baskı). Ankara: Pegem Yayınları.

- FLTSE, (2001). Foreign language teaching in schools in Europe: Eurydice studies. Brussels: Directorate General for Education and culture.

- Horwitz, E.K., (2001). Language anxiety and achievement. Annual Review of Applied Linguistics 21, 112-126.

- Kocaman, A., (1983). Yabancl Dil Öğretiminde Yeni Yöntemler. Orta Öğretim Kurumlarında Yabancı Dil Eğitimi ve Sorunlar, Türk Eğitim Derneği Bilimsel Toplantısı.

- Meletıi, F., (2007). Yabancı Dil Öğretimi Yapılan Sınıflarda Çoklu Zeka Kuramı ve Yabancı Dil Kullanımı. Ankara: Ankara Üniversitesi Sosyal Bilimler Enstitüsü.

- Murray, L.M. and Fogliasso, C.E., (2011). Testing the efficacy of self-affirmation in improving student performance in a business law course. Administrative Issues Journal 3, 50-53.

- Nunan, D., (1993). The Learner-Centered Curriculum, a Study in Second Language Teaching. Bell \& Bain Ltd, Glasgow, Cambridge University Press.

- Little, D., (1995). Learning as dialogue: the dependence of learner autonomy on teacher autonomy. System, 23(2), 175-82.104

- Özen, A., (1975). A Guide for Methodology and Practice Teaching, Ankara: 1975

- Sert, N., (2008). The language of the instruction dilemmain the Turkish context. System 36 (2008) 156-171,

- TBC: TFOE, (2000). The British Council: The future of English? http://www.britishcouncil.org /learning-elt-future.pdf Adresinden Kasım 10, 2010 tarihinde erişilmiştir.

- Yüksek Öğretim Kurulu. http://www. dha.com.tr/haberdetay.asp?tarih=14.08.2011\&Newsid=165 932\&Categoryid=3, 17 Haziran 2012 tarihinde erişilmiştir.

- Yaşar, Ş., (1988). Yabancı Dil Öğretiminde Programlı Öğretim Uygulaması. Eskişehir: T.C Anadolu Üniversitesi Sosyal Bilimler Enstitüsü. 